\title{
Preparation of Alumina-Silica Composite Coatings by Electrophoretic Deposition and their Electric Insulation Properties
}

Hye Ji, Doo Hwan Kim, Hee Jeong Park, Hyung Mi Lim ${ }^{\dagger}$, Seung-Ho Lee, Dae Sung Kim, and Younghee Kim

Energy \& Environmental Division, Korea Institute of Ceramic Engineering \& Technology, Seoul 153-801, Korea (Received September 30, 2013; Revised February 12, March 5, 2014; Accepted March 7, 2014)

\section{EPD 방법을 이용한 알루미나-실리카 복합 코팅막의 제조와 전기절연 특성}

\author{
지 혜 · 김두환 · 박희정 · 임형미 ${ }^{\dagger}$ - 이승호 · 김대성 · 김영희 \\ 한국세라믹기술원 에너지환경소재본부 \\ (2013년 9월 30일 접수 ; 2014년 2월 12일, 3월 5일 수정 ; 2014년 3월 7일 채택)
}

\begin{abstract}
Alumina-silica composite coating layers were prepared by electrophoretic deposition (EPD) of plate-shaped alumina particles dispersed in a sol-gel binder, which was prepared by hydrolysis and the condensation reaction of methyltrimethoxysilane in the presence of colloidal silica. The microstructure and the electrical and thermal properties of the coatings were compared according to the EPD process parameter: voltage, time and the content of the plate-shaped alumina particles. The electrical insulation property of the coatings was measured by a voltage test. The coatings were prepared by EPD of the sol-gel binder with 5-30 wt $\%$ plate alumina particles on parallel electrodes at a distance of $2 \mathrm{~cm}$ for 1-10 min under an applied voltage of 10-30 V. The coatings experienced increased breakdown voltage with increasing thickness. However, the higher the thickness was, the smaller the breakdown voltage strength was. A breakdown voltage as high as $4.6 \mathrm{kV}$ was observed with a $400 \mu \mathrm{m}$ thickness, and a breakdown voltage strength as high as $27 \mathrm{kV} / \mathrm{mm}$ was achieved for the sample under a $100 \mu \mathrm{m}$ thickness.
\end{abstract}

Key words : Sol-gel, Plate-shaped alumina, Electrophoretic deposition, Electrical insulation coating, Breakdown voltage

\section{1. 서 론}

전자기기가 소형화, 다기능화, 대용량화를 추구함에 따 라 전자 부품이 고밀도화, 고집적화가 되고 있다. 그러나 부품의 고밀도화는 기기 내에 많은 열을 발생시키며, 기 판에 탑재되어 있는 부품을 기판과 단락시키거나 부품의 기능을 저하시킴으로써 전자기기의 수명단축과 효율 저 하의 원인이 되고 있다. ${ }^{1)}$ 이러한 전자기기의 수명 연장 및 고효율화를 이루기 위하여 기기 내에 생성되는 열을 빠르게 방열시킬 수 있는 고성능 전기절연 코팅에 대한 요구가 높다. 이 코팅소재는 우수한 방열 및 전기절연 특 성과 함께 내열 특성이 요구되는데, 일반적인 수지의 경 우 내열온도가 낮지만 폴리아미드 이미드계 수지 및 실 리콘계 수지 등은 상대적으로 높은 내열 특성을 보인다. 세라믹의 경우 방열, 전기절연, 내열특성은 우수하지만, 고온의 소결공정을 필요로 하며 사용가능한 기판에 제한

\footnotetext{
${ }^{\dagger}$ Corresponding author : Hyung Mi Lim

E-mail : lim@kicet.re.kr

Tel : +82-2-3282-2448 Fax : +82-2-3282-7773
}

이 있을 수 있다. 또한 저온소성형 세라믹으로 졸-겔 반 응을 통한 네트워크를 만들 수 있으나, 후막의 제조는 쉽 지 않다. 열전도성의 경우 일반적으로 금속, 세라믹, 고분 자수지 순으로 낮아지며, 소재의 종류 및 구조, 복합체인 경우 계면 특성 등에 의존한다. 수지 단독으로 사용되는 경우보다는 고열전도 세라믹 필러를 사용하여 수지의 열 전도 특성을 높인 절연 복합소재를 제조하는 것이 가능 하다.

에폭시-실리카, 에폭시-알루미나 복합소재의 절연특성 연구에 따르면, 에폭시 수지에 수 수십 마이크로미터의 구형 알루미나 입자를 $50 \sim 70 \mathrm{wt} \%$ 충진하여 알루미나의 크기와 함량에 따라 $39 \sim 44 \mathrm{kV} / \mathrm{mm}$ 범위의 절연강도를 가 지는 절연 복합체를 제조하였다. ${ }^{2}$ 또한 에폭시 수지에 크 기가 다른 구형 실리카 입자를 일정 비율로 혼합하여 절 연 복합체를 제조하는 연구도 진행되었다. 이때 제조된 절연복합체는 입자의 크기가 $5,20 \mu \mathrm{m}$ 인 실리카 입자의 혼합비율과 충진 함량에 따라 $47 \sim 54 \mathrm{kV} / \mathrm{mm}$ 의 범위의 절 연파괴강도를 가진다. ${ }^{3)}$

에폭시 수지로 제조하는 복합소재의 경우 $\mathrm{mm}$ 단위의 두꺼운 절연막을 형성할 수 있다. 그러나 에폭시 수지의 염 
소기에 의한 전기적 문제와 무기물을 첨가하여도 $120^{\circ} \mathrm{C}$ 에 서 분해되기 시작하는 열안정성 문제 및 방열 특성의 개 선을 위하여 할로겐 원소가 잔류하지 않으며 열안정성이 좋은 절연코팅 재료에 대한 연구가 진행되고 있다.

세라믹코팅은 유기수지에 비해 열안정성과 방열 특성 은 우수하지만, 고온의 소결을 거쳐야하는 단점이 있으나, 졸-겔 공정을 통해 제조되는 세라믹코팅은 저온소성 공정 으로 제조가 가능하다. 졸-겔 공정으로 $\mathrm{MgO}-\mathrm{ZrO}_{2}$ 복합소 재 코팅막을 제조하고, $1000^{\circ} \mathrm{C}$ 까지 열중량 분석을 하여도 무게손실이 $17 \%$ 이고, 절연파괴강도가 $50 \mathrm{kV} / \mathrm{mm}$ 인 절연 코팅을 제조하는 연구도 진행되었다. ${ }^{4}$ 졸-겔 공정을 통하 여 저온에서 코팅막의 제조가 가능하지만, 치밀하고 결함 없는 후막의 제조는 어렵다. 마이크론 크기의 알루미나 입자가 포함된 졸-겔 코팅액도 1 회 스프레이 코팅으로 $10 \sim 25 \mu \mathrm{m}$ 두께의 도막이 형성되어 절연특성 향상을 위 해서는 반복 코팅이 필요하다. 그 과정에서 생성되는 잔 류 기공으로 $300 \mu \mathrm{m}$ 도막에서 약 $3 \mathrm{kV}$ 수준의 절연파괴 전압 특성을 보이고, 기공을 메우기 위해 졸-겔액을 침투 시키거나 실리콘-실란트로 표면 처리를 하여 $300 \mu \mathrm{m}$ 두 께에서 $5 \mathrm{kV}$ 로 향상된 절연특성을 보였다.)

전기영동적층법(Electrophoretic deposition, EPD)은 콜로 이드상에서 분산된 입자가 전하를 띠고 있어 전기장을 가 해주면 음극 또는 양극으로 입자의 이동이 발생하는 특 성을 이용한 코팅방법으로, 코팅하는 입자의 종류에 제한 없이 전기영동 특성을 보이기만 하면 금속, 고분자, 세라 믹 어떤 소재든지 코팅이 가능한 장점을 가지고 있는 방 법이다. 간단한 형태의 구조, 경제적 프로세스 그리고 기

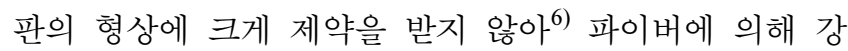
화된 세라믹 복합체, 다공체 막, 단열재료, 슈퍼커패시터, 연료전지, 전자 장비, 보호 코팅, 강유전체, 압전 및 자기 장치 및 바이오 분야의 임플란트 등 그 응용분야가 증가 하고 있다. ${ }^{7}$

$\mathrm{EPD}$ 의 주요 변수는 크게 현탁액과 $\mathrm{EPD}$ 공정 변수로 구분 할 수 있다. 현탁액의 특성으로는 입자의 크기 및 형상(판상, 구형, 파이버 등), 안정성, 전구체의 조성(입자, 수지, 용매, 첨가제, 바인더 등) 및 점도, 용매의 점도와 전도도 등이 있다. 그리고 $\mathrm{EPD}$ 공정에서는 전압, 적층 시 간, 기판 간 거리, 기판의 종류 및 표면 상태, 전도도 등 이 변수로 작용한다. ${ }^{6-8)}$ 졸-겔 코팅액의 $\mathrm{EPD}$ 는 단일 코팅 공정으로 수 $\mu \mathrm{m}$ 의 얇은 실리카 막을 제조하기에 유용한 방법이다. 그러나 이와 같은 막은 건조되는 과정에서 실 리카 입자의 수축이 발생함에 따라 균열이 발생하여 열 처리 공정이 필요하다. ${ }^{8)}$

본 연구에서는 졸-겔 반응을 이용하여 실리카 졸과 실 란을 출발 물질로 한 코팅제에 판상 알루미나 입자를 첨 가하여 EPD 방법으로 전기절연 코팅막을 제조하였다. 이 때, 판상 알루미나 입자의 함량과 $\mathrm{EPD}$ 공정에서 인가된
전압 및 시간을 변수로 하여 코팅막을 제조한 후 코팅막 의 물성을 비교하였다.

\section{2. 실험방법}

졸-겔 코팅제를 제조하기 위하여 MTMS (trimethoxymethylsilane, Dow corning)와 실리카 졸 TM-50 (Sigma Aldrich)을 사용하였다. 사용된 실리카졸의 입자 크기와 형 상은 Fig. 1의 TEM (JEM-2000EX, JEOL)으로 관찰하였 다. 구형의 실리카 입자 크기는 평균 $22 \mathrm{~nm}$ 이다. TM-50 의 $\mathrm{pH}$ 는 약 9.0 , 고형분 함량은 $50 \mathrm{wt} \%$ 이다. 실란의 가수 분해 반응을 균질한 분산상에서 이루도록 IPA(isopropyl alcohol, Dae Jung) 용매를 사용하고, 산촉매 조건에서 가 수분해 및 축합반응이 진행되어 polymeric network 구조 가 형성되도록 구성하였다. 건조조절제(drying control chemical additives)로 N,N-Dimethylformamide(Dae Jung) 을 사용하여 균열발생을 억제하였다.

Table 1 과 같은 조성으로 졸-겔 바인더 원료를 혼합하 고, $60^{\circ} \mathrm{C}, 250 \mathrm{rpm}$ 으로 30 분 동안 교반하여 가수분해 및 축합 반응을 실시한 뒤, 알루미나 입자 $5 \sim 30 \mathrm{wt} \%$ 를 첨 가하고 상온에서 $250 \mathrm{rpm}$ 으로 30 분 혼합하여, 충진량에 따른 코팅액을 제조하였다. 여기에 첨가한 알루미나 $\left(\mathrm{Al}_{2} \mathrm{O}_{3}\right.$, RonaFlair white sapphire, Merck)의 입자 형상과 평균입경 은 SEM(scanning electron microscope, SM-300, Topcon) 과 레이저 회절/산란식 입자분포측정장치(LA-950, Horiba) 로 관찰하였다. Fig. 2와 Fig. 3에서와 같이 알루미나 입

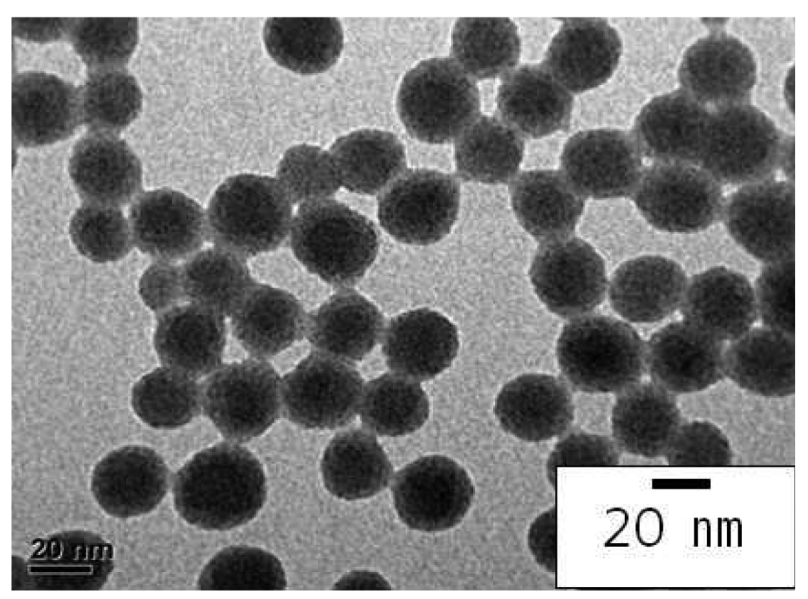

Fig. 1. TEM image of silica sol.

Table 1. Composition of Sol-gel Coatings Composed of Silica Sol and Silane (wt \%)

\begin{tabular}{ccccc}
\hline Silica sol & Silane & Acid & IPA & DCCA \\
\hline 41.3 & 47.0 & 1.0 & 9.5 & 1.2 \\
\hline
\end{tabular}




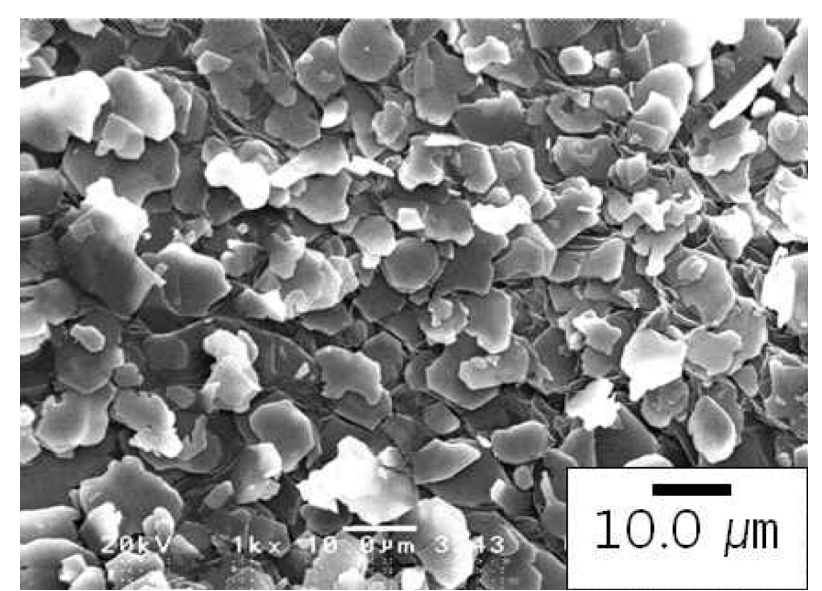

Fig. 2. SEM image of plate-shaped $\mathrm{Al}_{2} \mathrm{O}_{3}$.

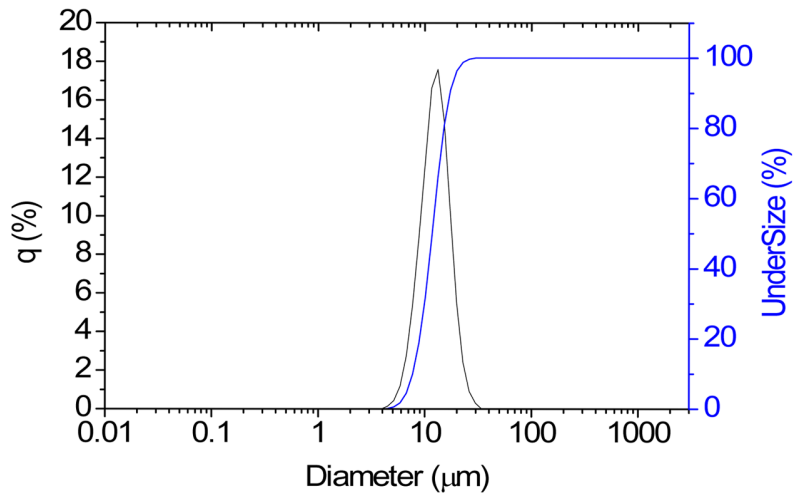

Fig. 3. Particle size distribution of $\mathrm{Al}_{2} \mathrm{O}_{3}$.

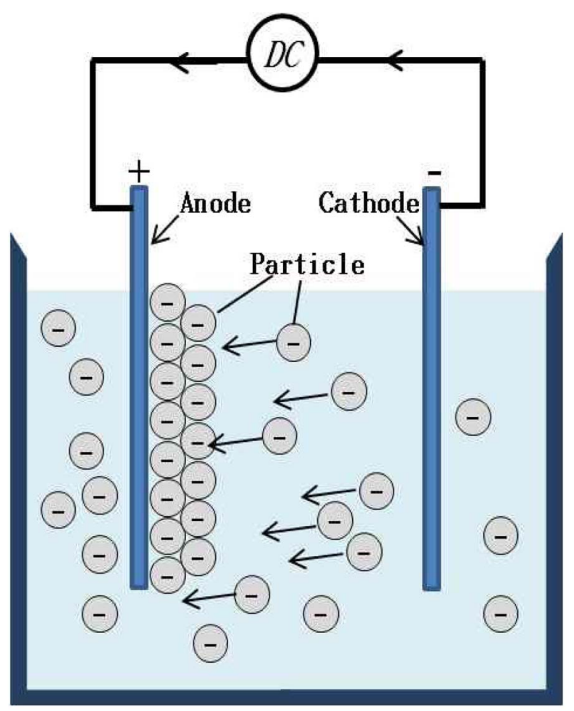

Fig. 4. Schematic illustration of electrophoretic deposition process.

자는 판상 형태로 평균 크기가 $12 \mu \mathrm{m}$ 임을 관찰하였다.

Fig. 4는 출발물질로 실란과 실리카 졸에 판상 알루미

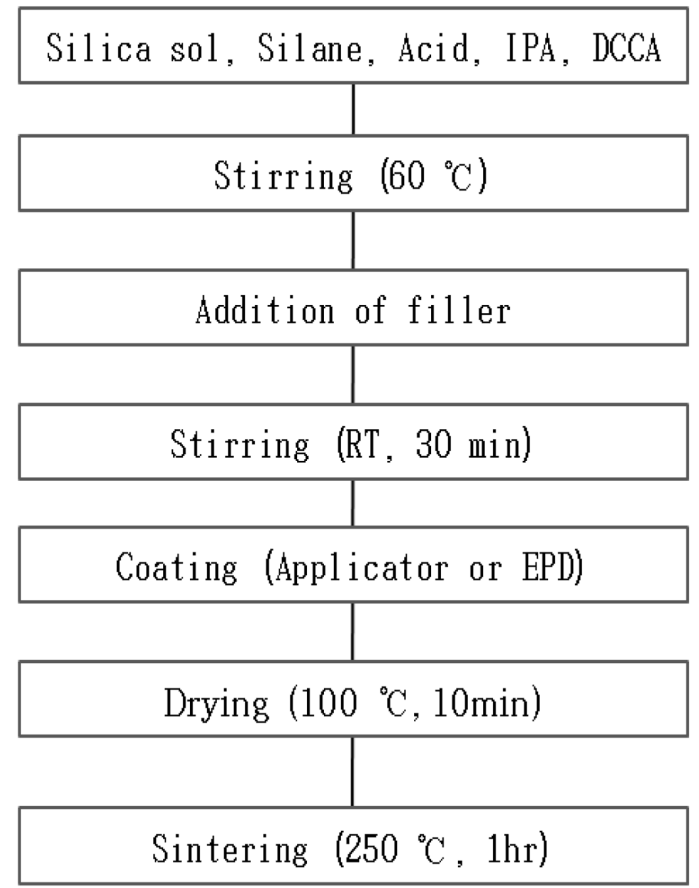

Fig. 5. Fabrication process of organic-inorganic hybrid coatings.

나 입자를 첨가하여 제조한 코팅제에 코팅기판을 담그고 전류를 가하여 전기영동적층법(EPD) (Fig. 4)으로 코팅하 였다. 전극으로 사용된 기판은 $30 \times 40 \times 1 \mathrm{~mm}$ 크기의 스 테인리스 스틸(SUS 304)을 에탄올로 탈지한 후 사용하였 다. $\mathrm{EPD}$ 공정 변수 중 인가된 전압 및 시간을 변수로 선 택하고 수직 평행하게 배치된 기판 간 거리는 $20 \mathrm{~mm}$ 로 고정하였다. 또한 현탁액에서는 판상 알루미나 입자의 함 량을 변수로 정하여 실험을 진행하였다. 이때 전압은 $10 \sim 30 \mathrm{~V}$, 전압 인가시간은 $1 \sim 10$ 분간의 변화를 주었다. 코팅한 기판은 $100^{\circ} \mathrm{C}$ 에서 10 분간 건조 후, $250^{\circ} \mathrm{C}$ 에서 60 분간 열처리하였다(Fig. 5). 이 때, 열처리 조건은 승온 속 도 $5^{\circ} \mathrm{C} / \mathrm{min}$, 냉각 속도는 $2^{\circ} \mathrm{C} / \mathrm{min}$ 로 설정하였다.

$\mathrm{EPD}$ 법으로 코팅하여 얻은 코팅막의 두께는 도막두께 측정기(MiniTest 600, Elektrophysik)로 측정하였으며, $\mathrm{SEM}$ 으로 파단면 및 표면의 미세구조를 관찰하였다. 전기적 특성을 확인하기 위하여 절연파괴전압(breakdown voltage) 을 내전압측정기(TOS 5101, KIKUSUI)로 측정하였다.

\section{3. 결과 및 고찰}

\subsection{EPD 도막의 형성}

$\mathrm{EPD}$ 도막을 제조하기 위해 사용된 코팅제 배합은 나노 크기의 실리카 입자와 MTMS 실란의 가수분해와 축합을 거쳐 생성된 올리고머 및 가수분해로 생성된 메탄올, 마 이크론 크기의 알루미나 입자가 물 용매에 분산된 현탁 액으로 구성되어 있다. 알루미나 입자가 분산된 현탁액 
내에 전기장을 걸면 입자가 이동하는 속도는 분산매 내 에서 분산된 입자의 표면전하 크기, 슬러리의 농도, 용매 의 유전율과 점도, 공존하는 입자와 이온의 양, 전기장의 세기, 전극 사이의 거리 등에 의존한다. 여기에서 실란의 가수분해와 축합반응은 실리카 입자 표면에서 일어날 수 있고, 표면전하가 $(+)$ 인 알루미나 입자표면의 정전기적인 인력으로 인해 실리카 나노입자 및 실리카 올리고머로 표 면이 개질되어 궁극적으로 알루미나 입자의 표면은 (-) 상태가 되어 양극(anode)으로 이동하여 기판에 쌓인다.

실리카 입자와 MTMS 올리고머로 표면이 코팅된 알루 미나입자가 적층된 양극 기판을 현탁액에서 분리하여 건 조하는 과정에서 수축이 심한 경우는 균열이 발생하면서 박리되지만, 알루미나 함량이 높아지면 수축이 감소되며 균열발생이 억제된다. 그 이유는 실리카 졸과 MTMS 올
리고머 표면에 포화된 물과 메탄올 용매가 휘발되면서 수 축이 일어나지만, 판상의 알루미나 입자 사이의 작은 공 간으로 스트레스가 분산되어 수축이 전파되지 않는 것으 로 추정된다. 즉, 알루미나 입자가 수축스트레스의 확산 을 막는 역할을 하는 것으로 생각된다. 일반적으로 세라 믹 입자의 $\mathrm{EPD}$ 공정을 성공적으로 적용하기 위해서는 건 조 및 소결공정에서 균열이 발생되는 문제를 제어하는 것 이 꼭 필요한데, 열처리 과정에서 발생하는 균열의 경우 는 에나멜 조성과 같이 용액상태를 거쳐 균열발생을 피 하거나, 기판도 함께 수축하게 하는 방법을 적용할 수도 있다. ${ }^{8)}$

\subsection{EPD 도막의 두께 변화와 부착성}

판상 알루미나 입자 함량과 $\mathrm{EPD}$ 공정 조건 중에서 인

Table 2. Properties of the Coating Layers Fabricated by Varying of Contents of $\mathrm{Al}_{2} \mathrm{O}_{3}$ Filler, Applied Voltage and Time

\begin{tabular}{|c|c|c|c|c|c|c|}
\hline No. & $\begin{array}{c}\mathrm{Al}_{2} \mathrm{O}_{3} \\
\text { Filler }(\mathrm{wt} \%)\end{array}$ & $\begin{array}{l}\text { Voltage } \\
(\mathrm{V})\end{array}$ & $\begin{array}{l}\text { Time } \\
(\mathrm{min})\end{array}$ & $\begin{array}{c}\text { Thickness } \\
(\mu \mathrm{m})\end{array}$ & $\begin{array}{c}\text { Breakdown voltage } \\
\left(\mathrm{kV}_{\mathrm{DC}}\right)\end{array}$ & $\begin{array}{c}\text { Breakdown strength } \\
(\mathrm{kV} / \mathrm{mm})\end{array}$ \\
\hline 1 & 5 & \multirow{12}{*}{10} & \multirow{4}{*}{1} & 35 & 0.78 & 22 \\
\hline 2 & 10 & & & - & 0.75 & - \\
\hline 3 & 20 & & & 124 & 1.66 & 13 \\
\hline 4 & 30 & & & 92 & 1.43 & 16 \\
\hline 5 & 5 & & \multirow{4}{*}{5} & 126 & 1.20 & 9.6 \\
\hline 6 & 10 & & & 55 & 0.98 & 18 \\
\hline 7 & 20 & & & 90 & 1.34 & 15 \\
\hline 8 & 30 & & & 120 & 1.69 & 14 \\
\hline 9 & 5 & & \multirow{4}{*}{10} & - & - & - \\
\hline 10 & 10 & & & 139 & 1.26 & 9.0 \\
\hline 11 & 20 & & & 164 & 2.08 & 13 \\
\hline 12 & 30 & & & 91 & 1.16 & 13 \\
\hline 13 & 5 & \multirow{12}{*}{20} & \multirow{4}{*}{1} & 43 & 1.15 & 27 \\
\hline 14 & 10 & & & 76 & 1.62 & 21 \\
\hline 15 & 20 & & & 95 & 1.49 & 16 \\
\hline 16 & 30 & & & 179 & 2.04 & 11 \\
\hline 17 & 5 & & \multirow{4}{*}{5} & - & - & - \\
\hline 18 & 10 & & & 169 & 1.50 & 8.9 \\
\hline 19 & 20 & & & 150 & 1.55 & 10 \\
\hline 20 & 30 & & & 318 & 3.69 & 12 \\
\hline 21 & 5 & & \multirow{4}{*}{10} & - & - & - \\
\hline 22 & 10 & & & - & - & - \\
\hline 23 & 20 & & & 218 & 2.80 & 16 \\
\hline 24 & 30 & & & 401 & 4.61 & 11 \\
\hline 25 & 5 & \multirow{4}{*}{30} & \multirow{4}{*}{10} & 194 & 1.89 & 9.8 \\
\hline 26 & 10 & & & 361 & 3.03 & 8.4 \\
\hline 27 & 20 & & & 524 & 4.02 & 7.7 \\
\hline 28 & 30 & & & 509 & 4.18 & 8.2 \\
\hline
\end{tabular}



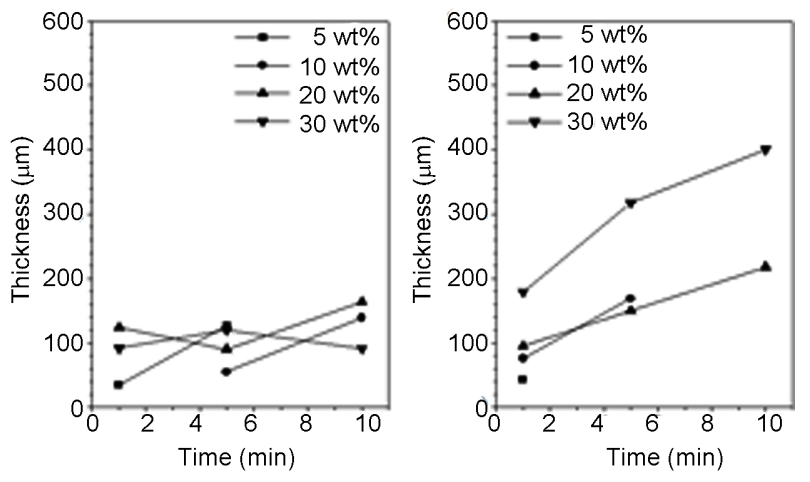

Fig. 6. Thickness of coating layers prepared by varying applied voltage time and $\mathrm{Al}_{2} \mathrm{O}_{3}$ content at applied voltages of (a) $10 \mathrm{~V}$ and (b) $20 \mathrm{~V}$, respectively.

가된 전압 및 시간을 변수로 하여 제조한 코팅막의 물성 은 Table 2와 같다. Fig. 6에서와 같이 도막의 두께는 전 압 인가시간이 길수록, 코팅제 내 알루미나 함량이 높을 수록, 인가전압이 높을수록 전반적으로 두꺼워지는 경향 이다. 그러나 $10 \mathrm{~V}$ 에서는 그 증가패턴이 뚜렷하지 않고 알 루미나 함량이 $20 \sim 30 \mathrm{wt} \%$ 로 높아지는 경우 시간에 따른 도막두께의 증가폭은 편차범위 이내이다. 또한 Fig. 6(b) $20 \mathrm{~V}$ 조건에서는 시간경과에 따른 증가패턴이 더 뚜렷하 지만, $5,10 \mathrm{wt} \%$ 의 판상 알루미나를 첨가하여 코팅막을 제조하는 경우, 코팅제 내의 입자의 함량이 상대적으로 적어 인가시간이 길어질수록 적층두께가 올라가고, 건조 과정에서 발생하는 코팅막의 균열 억제가 어려워 부착성 있는 도막의 제조가 어렵다. 또한 $20 \mathrm{~V}, 30 \mathrm{wt} \%$ 조건에서 는 코팅막이 일정 두께 이상으로 증가할 경우 코팅막의 절연성이 높아져서 현탁액에 걸리는 전기장의 세기가 상 대적으로 낮아져 두께가 증가하는 폭이 작아진다. 10 분 동안 $30 \mathrm{~V}$ 조건에서는 알루미나의 함량을 $5 \mathrm{wt} \%$ 에서 $20 \mathrm{wt} \%$ 로 증가함에 따라 도막두께가 증가하지만, $30 \mathrm{wt} \%$ 에서는 더 이상 도막두께가 증가하지 않는 경향을 보인 다. 이는 함량의 증가에 따른 점도 상승과 이동도 저하, 코팅시간 경과에 따라 전극의 절연특성이 높아져 결과적 으로 분산된 입자에 걸리는 전기장의 크기가 작아지는 효 과로 도막두께의 증가에 한계가 있는 것으로 생각된다.

한편 현탁액 내 판상 알루미나 입자의 함량이 $30 \mathrm{wt} \%$ 로 동일한 조건에서 인가전압을 $10,20,30 \mathrm{~V}$ 로 변화시켰 을 시 $20 \mathrm{~V}$ 조건에서 부착성이 가장 낮은데, 이는 알루 미나 입자의 적층과 배향으로 치밀성이 높은 도막이 형 성되어 상대적으로 졸-겔 바인더의 양이 적어 도막의 건 조과정에서 수축에 따른 일부 균열이 발생하여 부착성이 떨어지는 것으로 추정된다. 인가전압이 $10 \mathrm{~V}$ 인 경우 졸겔 바인더의 건조과정에서 일어나는 수축이 알루미나 입 자의 분산으로 인해 부착성이 유지되고 $30 \mathrm{~V}$ 의 높은 인 가 전압에서는 상대적으로 입자의 함량이 높고 다공성 막
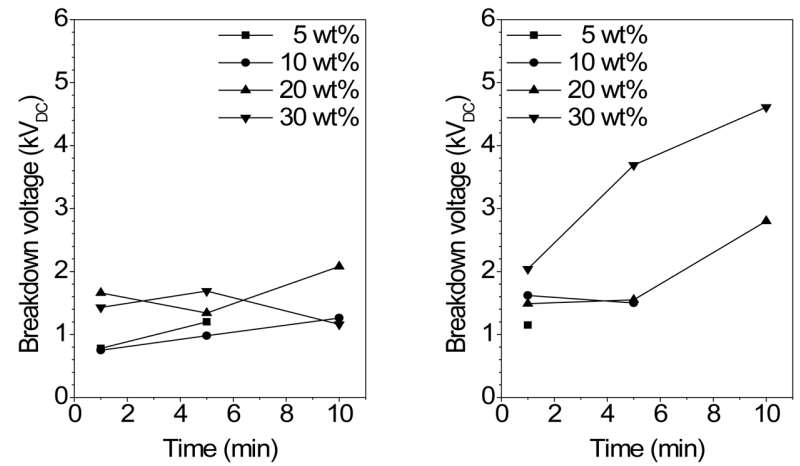

Fig. 7. Breakdown voltage of coating layers prepared by varying applied voltage time and $\mathrm{Al}_{2} \mathrm{O}_{3}$ content at applied voltages of (a) $10 \mathrm{~V}$ and (b) $20 \mathrm{~V}$, respectively.
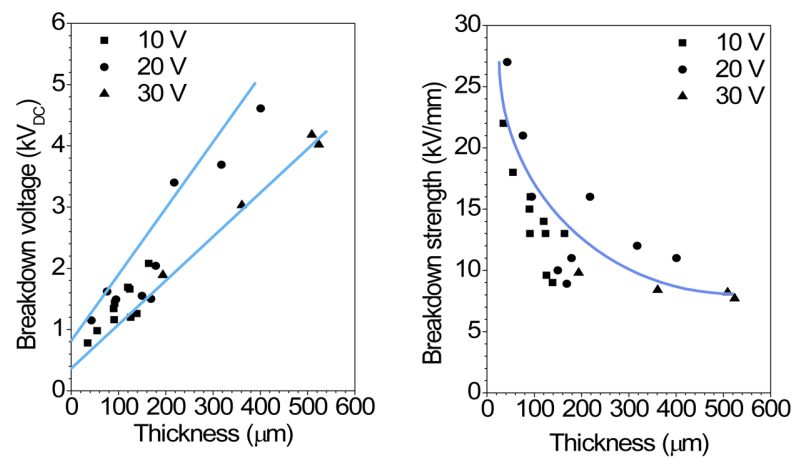

Fig. 8. (a) Breakdown voltage and (b) breakdown strength of coating layers according to the variation of thickness and applied voltage.

이 형성되어 건조과정에서 수축량이 상대적으로 적어서 부착성이 유지되는 것으로 보였다.

\subsection{EPD 도막의 절연파괴 특성}

Fig. 7은 전압 인가시간과 판상 알루미나의 함량에 따 른 도막의 절연파괴전압을 측정하였다. 인가전압이 $10 \mathrm{~V}$ 조건에서 생성된 도막의 경우, $1 \sim 2 \mathrm{kV}$ 내외의 절연파괴 전압이 측정되며, $20 \mathrm{wt} \%$ 의 판상 알루미나를 첨가하여 10 분 동안 전압을 인가하여 제조한 코팅막의 절연파괴전압 이 $2.1 \mathrm{kV}$ 로 가장 높았다. Fig. 7(b)의 인가전압이 $20 \mathrm{~V}$ 인 경우에는 $30 \mathrm{wt} \%$ 의 판상 알루미나를 첨가한 코팅막은 전 압 인가시간에 따른 절연파괴전압이 크게 증가하며, $30 \mathrm{wt} \%$ 의 판상 알루미나를 첨가하여 10 분 동안 전압을 인가하여 제조한 코팅막의 절연파괴전압이 $4.6 \mathrm{kV}$ 로 가장 높게 측정되었다.

Fig. 8은 코팅막의 두께와 절연 특성의 상관성을 보여 주고 있다. 코팅막의 두께가 증가할수록 절연파괴전압은 비례하여 증가하는데, 인가전압의 크기에 따라 절연파괴 전압이 다르게 나타났다. 즉, 동일한 두께의 도막이라도 인가전압의 크기가 $30 \mathrm{~V}$ 보다 $20 \mathrm{~V}$ 조건에서 제조한 시 

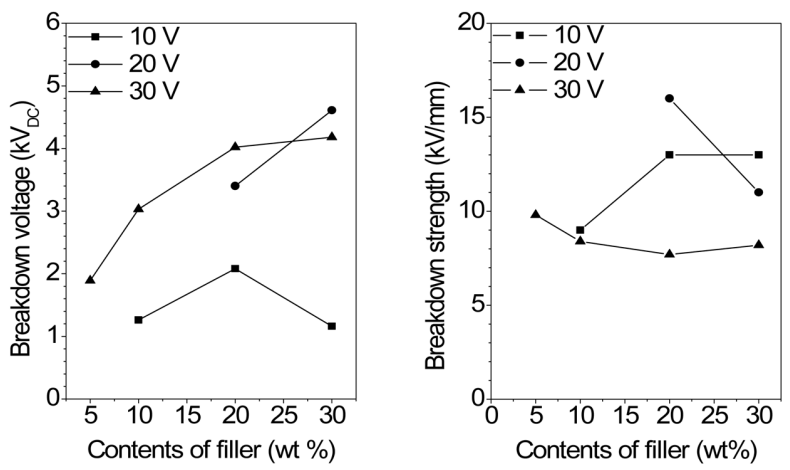

Fig. 9. (a) Breakdown voltage and (b) breakdown strength of coating layers, deposited for $10 \mathrm{~min}$, according to the increase of $\mathrm{Al}_{2} \mathrm{O}_{3}$ content.

편에서 오히려 절연파괴전압이 커진다. 인가전압이 너무 높은 경우 $\mathrm{EPD}$ 로 생성되는 도막의 치밀성이 상대적으로 떨어지는 도막이 생성될 수 있다. 한편 $10 \mathrm{~V}$ 조건으로 인 가전압이 더 낮아지면, 입자의 이동이 더 천천히 일어나 며 치밀도가 더 높은 도막을 제조할 수도 있다고 생각되 지만, 전압인가시간을 증가하여도 도막의 두께가 증가하 는 폭이 미미한데, 이는 입자의 적층으로 현탁액 내에 분 산된 입자에 걸리는 전기장의 세기가 작아지고, 따라서 전기영동 이동 속도가 현저하게 저하되는 것으로 추정된다.

Fig. 9에서는 현탁액의 알루미나 함량과 인가전압에 따 른 절연파괴전압과 절연파괴강도 변화를 나타내었다. 현 탁액 내 알루미나 함량 증가에 따라 절연파괴전압이 증 가하는 것은 도막의 두께가 증가하기 때문이다. 인가전압 $10 \mathrm{~V}$ 조건에서는 도막의 두께 변화가 크지 않고, 따라서 절연파괴전압의 변화도 미미하다. 그러나 도막의 두께로 나눈 값을 나타내는 절연파괴강도는 현탁액 내 알루미나 함량의 증가에 따라 오히려 감소하는 패턴을 보인다. $30 \mathrm{~V}$ 보다 $20 \mathrm{~V}$ 조건에서 절연파괴강도가 더 큰 것은 도막 내 의 결함이 적고 상대적으로 치밀한 조직이 형성되었기 때 문으로 추정된다.

\subsection{EPD 도막의 미세구조와 절연파괴전압 및 절연파괴강 도 특성}

코팅막의 두께가 증가함에 따라 절연파괴강도가 감소 하는 것은 코팅막의 단면 구조(Fig. 10)를 통하여 설명 할 수 있다. 판상 알루미나 함량 $5 \mathrm{wt} \%$ 를 첨가하여 제조한 코팅막 1(Fig. 10(a))과 13(Fig. 10(b))의 절연파괴강도는 $20 \mathrm{kV} / \mathrm{mm}$ 이상이 측정되며, 코팅막 단면 구조는 코팅막 에 판상 알루미나 입자가 거의 관찰되지 않으나, 빈 공간 이 거의 없이 졸-겔 구조로 구성되어 있는 것을 확인 할 수 있다. 절연파괴전압과 절연파괴강도는 도막의 치밀성 과 밀접한 관계가 있어, 치밀도가 높은 코팅막 1,13 의 절 연파괴강도가 높은 것으로 추정된다. 인가전압 $20 \mathrm{~V}$, 판

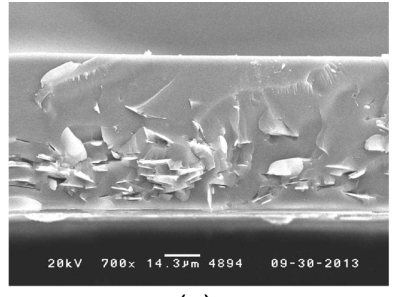

(a)

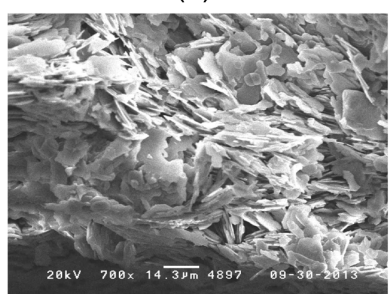

(c)

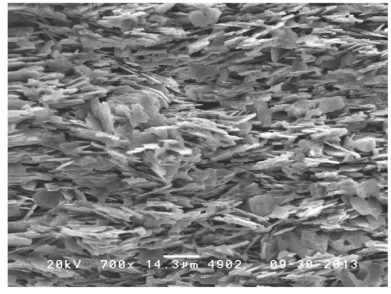

(e)

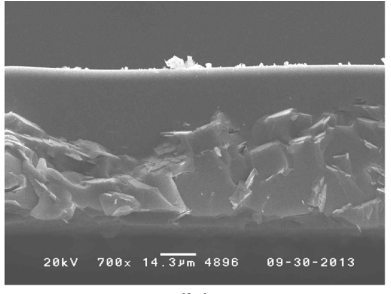

(b)

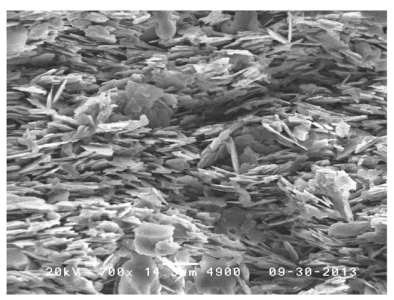

(d)

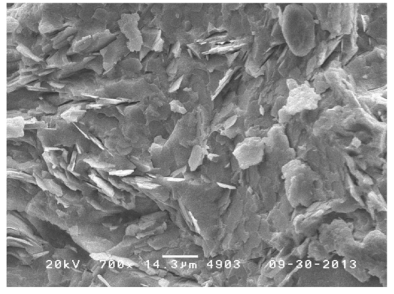

(f)
Fig. 10. SEM cross sectional views of coating layers of sample (a) 1, (b) 13, (c) 16, (d) 20, (e) 24, and (f) 28 .

상 알루미나 $30 \mathrm{wt} \%$ 조건의 코팅막은 전압 인가 시간에 따라 절연파괴강도는 $11 \sim 12 \mathrm{kV} / \mathrm{mm}$ 로 유사하나, 전압 인 가 시간이 $1,5,10$ 분으로 증가함에 따라 코팅막의 두 께와 절연파괴전압이 증가하는 것을 확인 할 수 있다 (Fig. 10(c) (e)). 여기서 전압인가시간 10 분인 코팅막 24(Fig. 10e)가 절연파괴전압이 $4.6 \mathrm{kV}$ 로 가장 높다. 이 코 팅막의 경우 $\mathrm{SEM}$ 을 통하여 관찰한 단면 구조는 판상 알 루미나 입자가 기판과 평행으로 위치하였으며, 입자가 치 밀하게 분포되었음을 확인 할 수 있다.

일반적으로 인가 전압이 증가함에 따라 코팅막 내의 판 상 알루미나의 입자의 배향성이 증가하고, 두께가 증가함 에 따라 절연파괴전압이 증가할 것으로 예상되지만, 실제 $30 \mathrm{wt} \% 20,30 \mathrm{~V}$ 조건에서 $\mathrm{EPD}$ 결과 ${ }^{24,28)}$ 를 비교하면 $30 \mathrm{~V}$ 조건에서 더 두껍게 코딩되었어도, 파단면의 미세구조를 살펴보면 $20 \mathrm{~V}$ 조건에서 생성된 도막의 배향성과 치밀성 이 더 높아져, 밀도가 최대가 되는 적정 전압 조건이 있 는 것으로 추정된다. 인가전압 $30 \mathrm{~V}$ 조건에서 제조된 코 팅막 28(Fig. 10(f))은 $20 \mathrm{~V}$ 조건의 코팅막 24(Fig. 10(e)) 와 비교하여 배향성이 떨어지는데 전압이 높은 경우 입 자의 이동속도를 빠르게 하여 도막의 적층속도가 빨라지 므로 동일 시간에서 가장 두꺼운 도막이 형성되지만, 배 향성이 저하되고 치밀한 구조를 이루기가 어려운 것을 추 정 할 수 있다. 


\section{4. 결 론}

출발 물질로 사용한 실란과 실리카 졸 코팅제 내에 판 상 알루미나 입자를 첨가하여 전기영동적층법을 통하여 세라믹 코팅막을 제조하였다. 이때 판상 알루미나 입자 의 함량과 인가전압, 전압 인가 시간을 공정 변수로 하 여 코팅막을 제조한 후 코팅막의 물성을 비교하였다. 최 대 $500 \mu \mathrm{m}$ 후막의 균열 발생 없는 코팅막을 제조할 수 있음을 알 수 있었다. 코팅제 내에 첨가된 판상 알루미나 입자의 함량이 $5 \sim 10 \mathrm{wt} \%$ 로 낮고 인가전압이 $10 \mathrm{~V}$ 일 경 우, 코팅막이 균일하게 형성되지 않아 전기적 특성을 측 정하기 어렵다. 그러나 상대적으로 높은 인가전압 $30 \mathrm{~V}$ 조건에서는 현탁액의 알루미나 함량이 높을수록 도막의 두께가 높아져서 절연파괴전압이 높은 절연도막을 얻을 수 있으나, 절연파괴강도는 낮아져 도막의 치밀성이 떨어 지는 것을 추정할 수 있다. 인가전압 $20 \mathrm{~V}$ 조건에서 얻어 지는 도막이 $30 \mathrm{~V}$ 조건에서 얻은 도막보다 동일한 두께 에서 더 높은 절연파괴전압을 보여서 도막의 치밀성이 높 을 것으로 추정된다. 실제 절연파괴강도도 $30 \mathrm{~V}$ 조건에서 얻어진 도막보다 $10-20 \mathrm{~V}$ 고함량 조건에서 얻어진 도막 이 절연파괴강도도 더 높았다. $30 \mathrm{wt} \%$ 현택액을 $20 \mathrm{~V}$ 조 건에서 전기영동 적층하여 얻은 도막은 시간 경과에 따 라 도막의 두께가 증가하며 초기에 특히 그 증가속도가 빠르다. 이렇게 얻은 도막의 파단면을 관찰하면 판상입자 가 기판과 수평으로 균일하게 배향되어 있어 치밀성이 높 은 도막을 얻을 수 있음을 알 수 있다.

\section{Acknowledgment}

이 논문은 미래창조부의 융합파이오니아 사업(NRF-20100019468)에 의하여 지원되었으며, 이에 감사드립니다.

\section{REFERENCES}

1. T. B. Jeon, Y. H. Kim, and S. H. Ma, "Analysis of PCB Manufacturing System Using Computer Simulation," J. Kor. Inst. Ind. Eng., 6 [2] 133-50 (1993).

2. J. J. Park, "Electrical Insulation Breakdown Strength in Epoxy/Spherical Alumina Composites for HV Insulation," Trans. Electr. Electron. Mater, 14 [2] 105-09 (2013).

3. J. J. Park, "Effect of Mmixing Ratio of Spherical Silica on the Electrical Insulation Breakdown Strength in Epoxy Composites," Trans. Electr. Electron. Mater., 14 [2] 101-04 (2013).

4. O. Cakiroglu, "High Voltage Breakdown Testing of Sol-gel $\mathrm{MgO}-\mathrm{ZrO} 2$ Insulation Coatings under Various Compressions at 298K and 77K," Moldavian J. Phys. Sci., 4 [1] 4953 (2005).

5. T. Oldinga, M. Sayer, and D. Barrow. "Ceramic Sol-gel Composite Coatings for Electrical Insulation," Thin Solid Films., 398-399 581-86 (2001).

6. L. Besra and M. Liu, "A Review on Fundamentals and Applications of Electrophoretic Deposition(EPD)," Prog. Mater. Sci., 52 [1] 1-61 (2007).

7. I. Corni, M. P. Ryan, and A. R. Boccaccini, "Electrophoretic Deposition: From Traditional Ceramics to Nanotechnology," J. Eur. Ceram. Soc., 28 [7] 1353-67 (2008).

8. K. Hasegawa, H. Nishimori, M. Tatsumisago, and T. Minami, "Effect of Poly (acrylic acid) on the Preparation of Thick Silica Films by Electrophoretic Sol-gel Deposition of Re-dispersed Silica Particles," J. Mater. Sci., 33 [4] 1095-98 (1998). 